January 1966

\title{
The Inter-American Commission on Human Rights
}

Ann Van Thomas Wynen

A. J. Thomas Jr.

\section{Recommended Citation}

Ann Van Thomas \& A. J. Thomas, The Inter-American Commission on Human Rights, 20 Sw L.J. 282 (1966)

https://scholar.smu.edu/smulr/vol20/iss2/4

This Article is brought to you for free and open access by the Law Journals at SMU Scholar. It has been accepted for inclusion in SMU Law Review by an authorized administrator of SMU Scholar. For more information, please visit http://digitalrepository.smu.edu. 


\title{
THE INTER-AMERICAN COMMISSION ON HUMAN RIGHTS
}

\author{
by \\ Ann Van Wynen Thomas" and A. J. Thomas, Jr.**

\section{The Inter-American System and Human Rights}

TN THE long slow development of international law, human rights have traditionally been the concern of the individual state. Each state recognized rights or withheld rights from its citizens according to its own standards, and no state could justifiably criticize the internal behavior of its neighbors. But in the inter-American system, there was an early recognition that a minimum of human rights should be of international concern. Bolivar's proposed Treaty of Union, League and Perpetual Confederation, discussed at the Congress of Panama in 1826, sought to establish a continental, international citizenship and in addition called upon all signatories to abolish slavery. ${ }^{1}$ This was a far cry from any extensive concept of individual human rights in all the countries of the hemisphere as a problem deserving international legal protection, and even this minimum failed to be adopted. In the years that followed, while political democracy or the more nebulous idealisms of democracy were vocally stressed at inter-American gatherings, human rights as such were virtually ignored.

Only since World War II has there been an admission in the Western Hemisphere that human rights are a subject of international concern; "that governments which systematically disregard the rights of their own people are not likely to respect the rights of other nations and other people and are likely to seek their objectives by coercion and force in the international field."' Several resolutions of the 1945 Inter-American Conference held in Mexico City dealt

* B.A., University of Rochester; LL.B., University of Texas; LL.M., Southern Methodist University. Research Associate, Southern Methodist University; Co-author with husband: Non-INtervention-The Law and Its Import in the Americas (1956); The Organization of American States (1963); The Dominican Republic Crisis 1965-Legal Aspects (1966).

** B.S., The Agricultural and Mechanical College of Texas; LL.B., University of Texas; LL.M. and S.J.D., University of Michigan. Professor of Law, Southern Methodist University; Chairman, Law School Division of Graduate Studies; Co-author with wife: NoN-INTERvention-The Law and Its Import in the Americas (1956); The Organization of american States (1963); The Dominican Republic Crisis 1965-Legal aspects (1966).

${ }_{1}$ Treaty of Perpetual Union, League and Confederation between the Republics of Colombia, Central America, Peru and the United Mexican States, July 15, 1826, arts. 24, 25, 27, set forth in International Conferences of American States 1889-1898, at xxviii (Scott ed. 1931).

${ }^{2}$ Marshall, No Compromise on Essential Freedoms, 19 Dep't State Bull. 432 (1948). 
with human rights, notably Resolution XL on International Protection for the Rights of Man, which proclaimed the adherence of the American republics to the principles established by international law for safeguarding the essential rights of man and declared support of a system of international protection of these rights. ${ }^{3}$ Apparently the resolution was not intended to indicate that violation of human rights was to be accepted as a breach of international law or even that such violation might constitute a threat to hemispheric peace, but rather was adopted "to eliminate the misuse of diplomatic protection of citizens abroad." The inalienable rights of man were still considered subordinate to principles of state sovereignty and non-intervention.

At the Rio Conference of 1947 , partisans of human rights introduced into the preamble of the Inter-American Treaty of Reciprocal Assistance (generally called the Rio Treaty), an idealistic (but nonlegal) statement that "the American regional community affirms as a manifest truth that ... peace is founded on justice and moral order, and, consequently, on the international recognition and protection of human rights and freedoms. ..." And when the Ninth International Conference of American States met the following year in Bogota, there was a strong movement ${ }^{6}$ to incorporate into the Charter of the Organization of American States (often known as the Charter of Bogota), a legal obligation binding each nation to respect human rights and fundamental freedoms, with a concomitant duty placed on the Organization of American States (OAS) to assure that each nation live up to its obligations in this respect. Those opposing argued $^{7}$ that the Charter was to be in the nature of a constitutional instrument and should be confined to provisions establishing the OAS and defining the nature, function and relationship of its organs, and that all other policies of the inter-American system should be set up in separate agreements. For the most part, this viewpoint prevailed, and the Charter generalizes about the legal duty to respect human rights and fundamental freedoms.

\footnotetext{
${ }^{3}$ Résumés of these resolutions may be found in PAU, MANUal of INTER-AMERican Relations 113-14 (Conf. \& Org. Ser. No. 26, 1953).

${ }^{4}$ PaU, Inter-American Conference on Problems of War and Peace, Report Submitted to the Governing Board of the Pan American Union by the Director General at 69 (Congress \& Conf. Ser. No. 47, 1945).

${ }^{3}$ The Rio Treaty is set forth in Appendix B, Thomas \& Thomas, The Organization of American States 429 (1963).

'PAU, Inter-American Judicial Committee Report to the Inter-American Council of Jurists Concerning Rfsolution XXXI of the Conference of Bogota 2 (1949).

${ }^{7}$ Ninth International Conference of American States (Report of the Delegation of the United States with Related Documents), Dep't of State Pub. 3263 , at $13(1948)$.
} 
The preamble declares "the true significance of American solidarity and good neighborliness can only mean the consolidation on this continent ... of a system of individual liberty and social justice based on respect for the essential rights of man." statements relating to the encouragement and promotion of respect for human rights and fundamental freedoms appearing in the Charter of the United Nations by a declaration that the signatories solemnly reaffirm the principles and purposes of the United Nations. And article 5 (j) of the Charter of the OAS states: "The American States proclaim the fundamental rights of the individual without distinction as to race, nationality, creed or sex." As none of these declarations were expressed in terms of a binding legal obligation, their sole utility was to leave open the way for further inter-American legislation by treaty in this field. However, article 13 of the Charter of Bogota observes: "Each State has the right to develop its cultural, political and economic life freely and naturally. In this free development, the State shall respect the rights of the individual and the principles of universal morality." It can be demonstrated that the final sentence of article 13 establishes a legal duty on the part of the states. Grammatically speaking, "shall" when used in third person expresses an obligation, a command. If the authors of article 13 had desired to express simple futurity, the article would have read "the state will. . . ." The word "shall" is here equivalent to the word "must." It is imperative, not merely directory. Consequently, article 13 can be interpreted to declare that each state has a legal right to develop its own way of existence, but in so doing it has the legal duty to respect the rights of individuals. But even if this interpretation is granted, neither individual states nor the OAS is given the right to take action to establish human rights in a state which fails in its obligation. Only if a violation of these values results in a threat to the peace of the hemisphere could collective action be undertaken under the terms of the Rio Treaty. ${ }^{\circ}$

Those seeking to give human rights international protection were not satisfied with these statements and demanded more. So a further action was taken at the Ninth Conference, namely the adoption of a resolution known as the American Declaration of the Rights and Duties of Man. ${ }^{10}$ This Declaration constitutes the first comprehensive intergovernmental statement of human rights in the history of

\footnotetext{
${ }^{8}$ The Charter of the Organization of American States is set forth in Appendix A, Thomas \& Thomas, The Organization of American States 413 (1963).

${ }^{9}$ See art. 6, Rio Treaty, op. cit. supra note 5 .

${ }^{10}$ Final Act, Resolution XXX, as contained in Ninth International Conference of American States, op. cit. supra note 7, at 260.
} 
the hemisphere. While it is nothing more than a statement of aims and hopes and was not intended to be legally binding, it has educational and inspirational value. And it indicates the deep concern of many statesmen for establishing an acknowledgment of the fact that there is a connection between the denial of human rights and acts of aggression against other nations implying that such denials constitute a continual threat to hemispheric peace.

Although the Declaration covers a wide variety of rights, it can be said that the most important rights are those which can be described as inalienable and fundamental; inalienable because under no circumstances can a nation justify a denial of them, and fundamental because a persistent denial of them would undermine and finally destroy any community based on democratic precepts. An ordered society, dedicated to the goals which democracy has set, really should not confer such rights on the individual, but should rather presuppose them. Among these rights would fall:

The right to life, liberty and personal security, (Art. 1)

The right to equality before the law, (Art. 2)

The right of fair trial, (Art. 18)

The right of protection from arbitrary arrest, (Art. 25)

The right to due process of law. (Art. 26)

The Ninth Conference at Bogota also recommended that the InterAmerican Juridical Committee prepare a draft statute providing for the creation and functioning of an inter-American court to guarantee the rights of man. ${ }^{11}$ After serious study, however, the committee unanimously decided that it would be impossible to create a court of this type until a formal convention on human rights had come into being which would govern all the nations of the Americas. ${ }^{12}$ At the Tenth Conference a resolution was adopted reaffirming that each nation should strengthen its system for the protection of human rights, and another resolution was adopted requesting the Council of the OAS to continue its studies on the juridical aspects of protection of human rights. ${ }^{13}$

While the inter-American system has not as yet developed legal norms from which human rights can be derived under positive law, it must be acknowledged that the Rio Treaty, the Charter of Bogota and the American Declaration of the Rights and Duties of Man have expanded the problem of human rights, at least partially, from the

${ }^{11}$ Resolution XXXI, Ninth International Conference of American States, op. cit. supra note 7 , at 266 .

12 PaU, Inter-American Council of Jurists, Inter-American Court to Protect THE RIGHTS OF MAN 2 (1953).

${ }^{13}$ PaU, Tenth Inter-American Conference-Final Act 34 (1954). 
national to the international level by the assertions in all of these instruments that the observance of human rights is now a matter of international concern.

\section{Functions and Powers of the Commission}

In 1959, the Fifth Meeting of Consultation of the Ministers of Foreign Affairs, ${ }^{14}$ gathered in Santiago, Chile, to consider hemispheric problems of an urgent and common nature, established by resolution a seven-man Inter-American Commission on Human Rights. ${ }^{15}$ This Commission was charged with furthering respect for such rights, and it was stated that the Commission was to have "the specific functions that the Council assigns to it." In 1960 the Council of the OAS adopted the Statute of the Inter-American Commission, article 9 of which outlines the functions and powers of the Commission as follows:

a) To develop an awareness of human rights among the peoples of America;

b) To make recommendations to the Governments of the member states in general, if it considers such action advisable, for the adoption of progressive measures in favor of human rights within the framework of their domestic legislation and, in accordance with their constitutional precepts, appropriate measures to further the faithful observance of those rights;

c) To prepare such studies or reports as it considers advisable in the performance of its duties;

d) To urge the Governments of the member states to supply it with information on the measures adopted by them in matters of human rights;

e) To serve the Organization of American States as an advisory body in respect to human rights. ${ }^{16}$

After the members of the Human Rights Commission were appointed, they debated the extent of their authority. The majority of the members decided that article 9-b "to make recommendations to the Governments of the member states in general" should be interpreted as meaning to make general recommendations to individual member states. ${ }^{17}$ Furthermore, even though its statute did not mention power to receive and examine communications from individuals, the Commission resolved that under its power to prepare such studies

\footnotetext{
${ }^{14}$ For reasons behind the convocation of this meeting see Stebbins, The UNITEd STATES IN WORLd AfFairs 352-56 (1959).

${ }_{15}$ PAU, La Organizacion de los Estados Americanos 1954-1959, at 12 (OEA/Ser. D/II.2 1959).

${ }^{10}$ PAU, Inter-American Commission on Human Rights, Report on the Work Accomplished During Its First Session, Oct. 2-28, 1960, at 9 (OEA/Ser.L/V/II.I, Doc. No. 32,1961 )

${ }^{17}$ Id. at 10 .
} 
and reports as it considered advisable, it could take cognizance by way of information, of written communications or claims received by it involving violations of human rights within the American states. ${ }^{18}$ As there was some complaint in the Commission itself that these interpretations were illegal under its statute, the Commission proposed at the same time that its competence should be broadened so as to give it more power; it felt that its obligation should not be limited simply to promoting respect for such rights, but rather it should be obligated to see that they are not violated. ${ }^{19}$

The Commission therefore drew up a series of requests to the Council suggesting that its statute be amended so that its power to examine complaints or violations, and prepare confidential reports including recommendations to the government accused of violating human rights, would be unquestioned. The Council of the OAS refused to amend the Commission's statute. The Commission then interpreted its own competence to include not only the power to recommend the adoption of general measures in favor of human rights within the framework of the domestic legislation of each state, but also to include the power to recommend to individual member states that each take, in accordance with its constitutional principles, appropriate measures to further the faithful observance of these rights. The Commission considered it proper to hear complaints by individuals and to request an accused government to give it a report regarding the measures that it was taking in the matter of violations of human rights which had been called to the attention of the offending government. ${ }^{20}$

It began flexing its investigative muscle during various meetings from April 1961 to May 1962, when it discussed communications relative to the grave situation in Cuba. ${ }^{21}$ Under its interpretation of its mandate, the Commission called the attention of the Government of Cuba to accusations lodged against it, suggesting that it live up to the American Declaration on the Rights and Duties of Man, and it requested Cuba to report on measures it was taking in the field of promotion of human rights. ${ }^{22}$ In reply, Cuba declared that neither article 9-b nor any other statutory provision authorized the Commission to concern itself with more than legislative, regulatory and general measures concerning human rights in each state. Cuba inti-

18 Id, at 13 .

19 Id. at 11 .

${ }^{20}$ Id. at 12 .

${ }^{21}$ PAU, Inter-American Commission on Human Rights, Report on the Situation of Political Prisoners and Their Relatives in Cuba at 1 (OEA/Ser.L/V/II.7, Doc. No. 4, 1963).

22 Id. at 2 . 
mated that anything beyond this would be an interference in the domestic affairs of the state, the operation of its specific organs, and the application of its laws. ${ }^{23}$ To this the Commission replied that its action was well founded since it interpreted the legal precepts of its statute in their natural sense which was derived from the basic principle that governs the function of the Commission, i.e., the mandate of the Organization of American States to "promote respect for human rights, as embodied in the American Declaration of Rights and Duties of Man.",24

The Cuban Government again disagreed with the interpretation given by the Commission to article 9-b and 9-d of its statute, and refused to answer further communications from the Commission. ${ }^{25}$ Consequently, based on the information, communications and complaints received, the Commission, in the absence of a reply from the Cuban Government, prepared and published a report on the lack of human rights in Cuba as such related to political prisoners and their relatives. ${ }^{26}$

The response of the Dominican Republic was exactly the opposite. At the beginning of its third session, held in October and November, 1961, the Commission requested of the Dominican Government permission to visit that nation to investigate complaints it had received of violations of human rights. ${ }^{27}$ The Dominican Government granted this permission on the understanding that the Commission would limit its study to violations which had taken place after the assassination of its former dictator, Rafael Trujillo. ${ }^{28}$ The Commission accepted this stipulation. On its visit, it gathered information on the arrests and disappearance of persons in the Dominican Republic, on the limitations of freedom of expression, and on problems arising from conflicts between governmental authorities and students and labor unions. On the basis of this information, the Commission submitted a report to the Dominican Government urging it to take immediate steps to advance human rights. It also published this report. ${ }^{29}$

The Eighth Meeting of Consultation of Ministers of Foreign Affairs recommended that the Council of the OAS revise the statute of

${ }^{23} \mathrm{Id}$. at 4

${ }^{24} I d$. at 6 .

${ }^{25} I d$. at 8 .

${ }^{26}$ Id. at 9 .

27 PAU, Inter-American Commission on Human Rights, Report on the Work Accomplished During Its Third Session, Oct. 2-Nov. 4, 1961, at 4 (OEA/Ser.L/V/II.3, Doc. No. 32, 1961)

${ }^{28}$ Id. at 5 .

29 PAU, Inter-American Commission on Human Rights, Report on the Situation Regarding Human Rights in the Dominican Republic (OEA/Ser.L/V/II.4, Doc. No. $32,1962)$. 
the Commission, in order to broaden and strengthen the Commission's functions and powers so as to permit it to further respect for human rights in the hemisphere more effectively. ${ }^{30}$ But the Council still refused to do so. ${ }^{31}$

In September 1962, having received complaints concerning denial of human rights in Haiti and in Nicaragua, the Commission decided that under its authority to hold its meetings in any American state when it so decided by an absolute majority of votes and with the consent of the government concerned, it would request permission from Haiti and Nicaragua to hold part of its sessions in those nations. ${ }^{32}$ Haiti replied that "the Commission has not laid down the basis for that request which can be interpreted as a form of interference in the internal affairs of the Republic of Haiti that affects its sovereignty,",33 and refused permission. Nicaragua on the other hand granted permission but left the date open, pending conversations on the matter between the chairman of the Commission and the Nicaraguan Government. ${ }^{34}$ The Commission suggested any time during December 1962 or January 1963, during a week that the Government would determine. But the Nicaraguan Minister of Foreign Affairs advised that the Government of Nicaragua, "taking into consideration special circumstances of a national and international nature regrets that it is not able to establish a possible date during those months." ${ }^{\text {,35 }}$ In view of the decision by the Commission to hold a Special Session in January 1963, the chairman of the Commission again addressed a cable to the Government of Nicaragua on November 1, 1962, informing it of the decision and reiterating the desire of the Commission to hold at least a part of the Special Session there. ${ }^{36}$ After an interval of more than two months, when the Special Session was already in progress, the Minister of Foreign Affairs of Nicaragua, wired that "it is not possible to designate the current month of January for Nicaragua to serve as the temporary seat of the Commission." ${ }^{37}$

\footnotetext{
${ }^{30}$ PAU, Inter-American Commission on Human Rights, Report on the Work Accomplished During Its Fourth Session, April 2-27, 1962, at is (OEA/Ser.L/V/II.4, Doc. No. 34, 1962).

31 PAU, InTER-American CoMmission ON HUMAN Rights, Report on the Work Accomplished During Its Sixth Session, April 16-May 8, 1963, at 18 (OEA/Ser.L/V/II.7, Doc. No. 28, 1963).

${ }^{32}$ PaU, Inter-American Commission on Human Rights, Report on the Work Accomplished During Its Fifth Sesston, Sept. 24-Oct. 26, 1962, at 8, 12 (OEA/Ser.L/V/II.5, Doc. No. 40, 1963).

${ }^{33} I d$. at 9.

${ }^{34}$ ld. at 13 .

${ }^{35} I d$. at 15 .

${ }^{36} I d$. at 16 .

37 PAU, Inter-American Commission on Human Rights, Report on the Work Accomplished During Its First Special Session, Jan. 3-23, 1963, at 11 (OEA/Ser.L/V/II.6, Doc. No. 18, 1963).
} 
After a careful study of this telegram, the Commission concluded that the Government had refused consent. The Government on various occasions had avoided setting a date, despite its apparent consent, and this signified that the Government of Nicaragua did not look with sympathy upon the Commission's holding part of its session on Nicaraguan territory for the purpose of ascertaining whether human rights were being observed in that country. ${ }^{38}$ In both the Haitian and Nicaraguan instances, the Commission issued a press release stating all of the facts, thus giving widespread publicity to the fact that these nations were accused of having violated fundamental human rights. ${ }^{39}$

In contrast, the Dominican Republic on November 1, 1962, invited the Commisison to visit that nation "for the purpose of completing the important mission it began in October 1961.", Since five of the seven members of the Commission participated in the First Symposium on Representative Democracy, which was held in Santo Domingo from December 17 to 22, 1962, and had therefore observed the national elections which had taken place on the twentieth of the month, the Commission felt that it had an opportunity on that occasion to verify the progress made by the Dominican people in the field of human rights. It thanked the Government for the invitation and placed on record the exemplary conduct of the Government. ${ }^{41}$

In 1963 the Commission again requested permission from the Government of Haiti to go to that country to study the situation regarding human rights and was again refused on the grounds that its visit might be interpreted as a form of interference in the internal affairs of the Republic of Haiti. ${ }^{42}$ The Commission made it expressly clear that it respected the sovereignty of Haiti but that it was empowered by article 11-c of its statute to visit the territory of any American state with prior consent of the government. Since the Commission was unable to further investigate various communications received from Haitian citizens containing accusations of serious and repeated violations of human rights in the Republic of Haiti, in accordance with article 9-c, of its statute, the Commission prepared and issued a report on the situation regarding human rights in that country. ${ }^{43}$

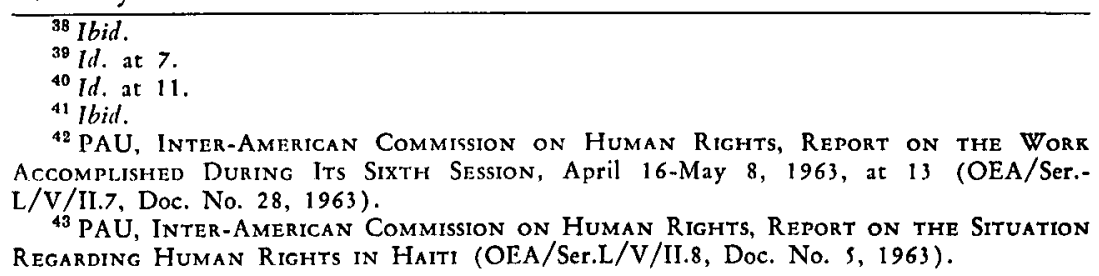


Under its statute the Commission is limited to discussion, study, investigation and recommendation, and, as can be gleaned from the above cases, some states contend that an exercise of this power specifically directed at an individual nation amounts to intervention in internal affairs which is prohibited both by the Charter of the United Nations and the Charter of the Organization of American States. These states follow a line of authority ${ }^{44}$ which declares that the ban on intervention in internal affairs was meant to include discussion, study and investigation; formal action by way of recommendation to a state within whose domestic jurisdiction the subject matter lies; and certainly all enforcement action. An acceptance of this view would, of course, seriously curtail the Commission's power of discussion, investigation and recommendation, for it would be bound by article 15 of the Charter which proscribes intervention in the domestic jurisdiction of a state.

But there are others who would dispute this interpretation. Intervention is a technical legal word involving interference with the internal or external affairs of a state without its consent in an attempt to make the will of the interfering agent prevail. ${ }^{45}$ Whether discussion, investigation or recommendations are to be considered acts of intervention by the Commission would depend on whether they were coercive attempts to maintain or alter existing conditions against the state's will.

Ordinarily discussion or investigation by organs of the OAS would not amount to intervention. Discussion and investigation are traditional methods of diplomacy and cannot be considered intervention so long as such discussion or investigation permits presentation of both sides of an issue and does not involve coercion. The fact that such discussion or investigation might mobilize against a nation whatever power may exist in the nebulous force of inter-American public opinion is insufficient to equate it with intervention, for to prohibit such discussion or investigation would be to close virtually all channels of communication between the organization and states or among states themselves.

But even if this view is accepted, there is a possibility that discussion and investigation would fall within the aegis of intervention. Since a state might lose international prestige through mobilization of public opinion against it, a discussion and investigation may have the effect of compelling a state to act in accord with the will of the Com-

\footnotetext{
${ }^{44}$ See, e.g., Preuss, Article 2, Paragraph 7 of the Charter of the United Nations and Matters of Domestic Jurisdiction, 74 RecueIL des Cours 593 (1949).

${ }^{45}$ On the definition and concept of intervention see Thomas \& Thomas, Non-INTervention, The Law and Its Import in the Americas 71 (1956).
} 
mission, even though no threat of other action is made. In such instances, if the Commission entered into a consideration, discussion or investigation directed against a specific state with the purpose of coercing that state to act in conformity with the will of the Commission, then this would seem interventionary. ${ }^{46}$

The same may be said as to a recommendation. Ordinarily a recommendation of a general nature suggesting a course or policy which all the states of the OAS should follow would be within the authority of the Commission. But a specific censorious recommendation made against a state for the purpose of forcing that state's will would seem to be intervention. ${ }^{47}$

Granting that discussion, investigation and recommendation might in some instances be interventionary in character, the problem then arises whether or not such action would always be violative of the non-intervention principle of the Americas. Some would say yes; others would disagree, pointing out that under the terms of the Rio Treaty the American regional community affirms as a manifest truth that peace is founded on the international recognition and protection of human rights and freedoms and the Bogota Charter speaks of the duty of promoting respect for human rights and fundamental freedoms. ${ }^{48}$ This indicates that the fundamental purpose behind the establishment of the inter-American juridical community was to bring about security and peace founded on law, justice and the protection of human rights. ${ }^{49}$ This fundamental purpose cannot be nullified by the non-intervention limitation of the Charter, for to do so would destroy the whole basic fabric and foundation of the inter-American system.

One highly important exception to the issue of intervention is the principle of consent. Under general international law prior or simultaneous consent is a valid basis for intervention. ${ }^{\text {so }}$ As all of the states of the hemisphere approved the Statute of the Commission on $\mathrm{Hu}$ -

46 The fact that states have banded together and formed an international organization places in that organization elements of power which single members of the international community can never possess to the same degree. Therefore, any action within the scope of authority of an international organization will tend to be of a mandatory nature if the values at issue are important to the member state involved, for a threat of loss of these values may compel it to Ibid. act in accord with the will of the organization.

${ }^{47}$ Kelsen, Limitations on the Functions of the United Nations, 55 YALE L.J. 997 (1946)

${ }^{48}$ See Lauterpacht, The International Protection of Human Rights, 70 RecueIL DEs Cours 14, at 21 (1947).

${ }^{49}$ Lleras, Report on the Ninth International Conference of American States, 1 ANNaLs of OAS $25-27$ (1949), U.N. GeN. Ass. OfF. Rec., 3d Sess., pt. II, at 46 (A/PV. 203) (1949).

${ }^{50}$ Ross, A Textbook of International Law 243 (1947). 
man Rights, there can be no question but that they gave their consent to the section of the statute which empowers the Commission to prepare such studies or reports as it considers advisable. But did this imply that the nations of the Western Hemisphere gave their consent to permit the Commission to hear complaints by individuals charging violation of human rights by specific governments? Some nations hold that it does not, that consequently when the Commission entertains such complaints, it is acting outside its authorized or constitutional power. Others would say that the preparation of studies and reports necessarily involves basic research, otherwise studies and reports are useless. In taking cognizance by way of information of individual claims against governments violating human rights, the Commission is merely engaged in basic research; and the prior consent of the nations to the statute would overcome any plea of illegality.

As to the Commission's power to make recommendations, the issue of consent is also important. Article 9-b states that the Commission has power to make "recommendations to the Governments of the member states in general." Some nations feel that this can only be interpreted as prohibiting the Commission from singling out any particular member state in making its recommendation, and hence no consent was given to permit the Commission to make specific recommendations to an individual member. The Commission itself interpreted its competence to mean that if it considered it advisable to make general recommendations to each individual member state, as well as to all of them, it might do so. ${ }^{51}$ It assumed consent to this interpretation.

There is yet another possibility here. It can be said that actually the Commission was defining the phrase in general under its dictionary meaning; that is, in general is equated with for the most part. ${ }^{52}$ Under this line of reasoning, Commission recommendations would for the most part, generally or normally, be made to the governments of member states, either individually or collectively, but if it so deemed necessary the Commission could make recommendations to other groups such as international organizations, non-governmental private organizations, or even such groups as organized rebels seeking to overthrow a government in power. This would mean that prior consent had been given for Commission recommendations to individual governments.

\footnotetext{
51 PAU, Inter-American Commission on Human Rights, Report on Work ACCOMplished During Its First Session, Oct. 3-28, 1960, at 10 (OEA/Ser.L/V/II.I, Doc. No. 32, 1961).

52 "-in general . . generally, for the most part . . " WeBster's New INTER National Dictionary of the English Language 1044 (2d ed. 1940).
} 


\section{The Commission and the 1965 Dominican Republic CRisis}

On April 24, 1965 revolution flared in the Dominican Republic, sparked in part by disagreement between two factions in the armed forces of that nation. ${ }^{33}$ The rebel faction, which came to be known as the "Constitutional Government," was opposed by a loyalist group, which came to be known as the "Government of National Reconstruction." On the second day of the revolution, the President of the Dominican Republic resigned and went into hiding. At first the rebels seemed to be gaining victory and installed a provisional president, but within two days their cause appeared so hopeless that certain of the rebel leaders, including the provisional president, sought asylum in foreign embassies. Not until May 3 did identifiable leadership of the rebel faction emerge. The loyalists had on April 28 formed a three-man military junta to govern the country, but as the two factions were at an approximate stage of stalemate by that date, the country was without an effective government. During this dangerous power vacuum, violence and anarchy blanketed the nation, and the military junta admitted to the authorities of the United States Embassy in Santo Domingo that it was unable to cope effectively with the threat posed by the rebels, and consequently could not guarantee the safety of the citizens of the United States or other foreign nationals in Santo Domingo. It therefore requested the assistance of United States military personnel for this purpose. On April 28 , in response to this request, the President of the United States landed Marines on Dominican soil.

One of the stated purposes for landing United States forces in the Dominican Republic was that of preserving the capacity of the OAS to function in the manner intended by that organization's Charter to achieve peace and justice through securing a cease-fire and through re-establishing orderly political processes within which Dominicans could choose their government free from outside interference.

The Chilean Representative to the Council of the OAS requested that the Council convene the Tenth Meeting of Consultation of American Ministers of Foreign Affairs on May 1, 1965, to consider the serious situation created by armed strife in the Dominican Republic. During its first plenary session, the Tenth Meeting authorized a five-man Special Committee, to proceed to the Dominican Republic to do everything possible to re-establish peace. This committee sought, and, after much negotiation, eventually obtained a cease fire agree-

\footnotetext{
${ }^{\mathbf{5 3}}$ For a comprehensive background to the revolution, and a discussion of the legality of the actions of the United States and the Organization of American States see THOMas \& Thomas, The Dominican Republic Crisis 1965-Legal Aspects (1966).
} 
ment from both sides. Having fulfilled its mandate, it was disbanded on May 20. In the meantime, on May 6, the Tenth Meeting adopted a resolution requesting governments of member states who were willing to do so to make available to the OAS contingents of their land, naval, air or police forces to form an Inter-American Peace Force which was to operate under the authority of the Tenth Meeting. Following this resolution, certain United States contingents were withdrawn from the Dominican Republic and the remainder were incorporated into the Inter-American Peace Force under a unified command. Seven Latin American nations offered forces, although with the exception of Brazil their numbers were small.

On June 2, the Tenth Meeting took an additional step toward reaching a political settlement in the Dominican Republic by appointing a three-man Ad Hoc Committee made up of representatives of Brazil, El Salvador and the United States. The chief goal of this Ad Hoc Committee was to establish a climate of peace and reconciliation that would permit the functioning of democratic institutions in the Dominican Republic and its economic and social recovery.

Early in May, 1965, the "Constitutional Government" requested the OAS to send the Inter-American Commission on Human Rights to the Dominican Republic to investigate violations of human rights. The same request was made by the "Government of National Reconstruction." This raised the issue of whether there was consent for the Commission to go to Santo Domingo to carry on investigations, for neither of these groups was recognized as the established government of the Dominican Republic; hence, neither could speak for the nation. But since both factions requested the presence of the Commission, it could be implied that there was consent of the whole state.

The Secretary General of the OAS also felt that the Commission should make a study, ${ }^{55}$ and the Commission went into the Dominican Republic with added competence under article 9-e of its statute which permits it to serve as an advisory body to the OAS.

Before the Commission began hearing complaints, it asked that each group agree (1) to respect and enforce observance of the human rights set forth in the American Declaration of the Rights and Duties of Man, and (2) to extend to the Commission all facilities necessary for proper fulfillment of its mission. Each group signed a separate document accepting these obligations. ${ }^{56}$

Only if one equates the term "in general" as it appears in article 9-b

${ }^{54}$ PAU, The Dominican Siluation, 1 The OAS Chronicle 1, at 6, 7 (Aug. 1965).

${ }^{55}$ Ibid.

se Id. at 8 . 
of the Commission's statute with its dictionary definition "for the most part" can the Commission's actions in the Dominican Republic be understood. In the Dominican Republic there were two groups, each claiming to be the legitimate government, neither of which had been recognized by the OAS. Yet the Commission made recommendations to both. If its power of recommendation were limited to recommendations to governments only all of its work in the Dominican Republic would have been ultra vires. However, under the dictionary interpretation, the Commission would be permitted on special occasions to give recommendations to other bodies.

After it addressed its request to the OAS, the "Constitutional Government" also sent a letter to the United Nations demanding the dispatch of the United Nations Commission on Human Rights to verify and take appropriate means to stop violations of human rights allegedly being committed by the "Government of National Reconstruction." This request again gave rise to the twenty-year-old question of the respective roles of the regional and the world communities in relation to peacekeeping. ${ }^{58}$

Inasmuch as the UN is the universal organization, it has been asserted that even though a complaining state is a member of a regional organization which has already taken the matter under consideration, access to the Security Council is never barred. This right of all members to appeal directly to the world forum is authorized by article 33 of the UN Charter. Moreover, under article 34, the Security Council may investigate a dispute or situation, and under article 39 if it finds a threat to the peace, breach of the peace, or act of aggression, it is authorized to determine proper measures for maintaining or restoring international peace. Even though article 52 permits regional agency settlement and calls upon the Security Council to encourage them, this article stipulates that it "in no way impairs the application of articles 34 and 35." In the Security Council debates on the Dominican crisis it was stressed that the Security Council had primary responsibility for the maintenance of international peace which could not be supplanted by the actions of the OAS. The Uruguayan Representative to the UN pointed out that despite certain precedents whereby the Security Council had decided to suspend consideration of a specific question pending a report from the OAS, at no time had the power of the Security Council to exer-

\footnotetext{
${ }^{57}$ U.N. Securiry Council, Provisional Verbatim Record of the Twelve Hundred and Eighth Meeting, pp. 2-3 (Provisional, S/PV. 1208, 14 May 1965).

${ }^{38}$ Id. at 11-30.
} 
cise the functions assigned to it by the UN Charter been challenged. ${ }^{58}$ The activities of the regional system could not derrogate from the authority of the Security Council. This apparently was also the view of the present Secretary General of the UN, for in a press conference relating to the Dominican situation he declared that he viewed the peace-keeping operations undertaken by the OAS as possibly establishing an embarrassing precedent, implying thereby that the Security Council should have taken control of the case. ${ }^{60}$

A strong rebuttal to this thesis can be made, for although the Security Council is given the primary duty to maintain or restore peace, the International Court of Justice has pointed out that the Security Council is not the only body which may act when threats to the peace occur. ${ }^{61}$ To the contrary, the Charter stipulates in article 33 that parties shall first seek a solution by negotiation, enquiry, mediation, conciliation, arbitration, judicial settlement, resort to regional agencies or arrangements, or through other peaceful means of their choice. In addition the Security Council is enjoined to call upon the parties to resort to these means when it deems necessary. Article 52 exhorts parties to a regional arrangement to submit disputes for settlement to such agency before referring them to the Security Council. Before is the operative word in this clause. Article S2 even requires the Security Council to encourage the pacific settlement of local disputes through regional agencies. The UN Charter recognizes the authority of the regional agency and, accordingly, regional agencies are an elemental part of the peace-keeping scheme of the Charter. Since the OAS and the UN have essentially the same goals it would seem that their missions are not mutually exclusive but are mutually reinforcing. This position has been affirmed by the majority of the American republics in earlier debates and was reasserted during the Security Council's discussion of the Dominican crisis by the Representative of the United States. It was observed that in the past the "Security Council recognized the advisability of encouraging regional efforts, and its confidence in the abilities of regional organizations to deal with their own problems has been justified by the record. ${ }^{.92}$ In order to end the debate on the primacy of

\footnotetext{
59 Statement of the Representative of Uruguay, Report of the Security Council, U.N. Security Council Off. Rec. GAOR: 20th Sess., Supp. No. 2, 16 July 1964 - 15 July 1965, at $96(\mathrm{~A} / 6002)(1965)$.

${ }^{60}$ As set forth in Garcia Amador, The Dominican Situation, The Jurisdiction of the Regional Organization, 17 Americas 1, at 3 (July 1965).

${ }^{61}$ Certain Expenses of the United Nations (Article 17, paragraph 2, of the Charter) Advisory Opinion of 20 July 1962, [1962] I.C.J. Rep. 1s1, at 163.

${ }^{62}$ Statement of the Representative of the United States, Report of the Security Council, op. cit. supra note 59 , at 94 .
} 
rights between the regional and the universal organizations, the Representative of Jordan offered a resolution which was unanimously accepted:

The Security Council:

Deeply concerned at the grave events in the Dominican Republic,

1. Calls for strict cease-fire;

2. Invites the Secretary-General to send, as an urgent measure, a Representative to the Dominican Republic for the purpose of reporting to the Security Council on the present situation;

3. Calls upon all concerned in the Dominican Republic to cooperate with the Representative of the Secretary-General in carrying out his task. $^{\text {es }}$

This compromise solution came under immediate attack. In a speech on the floor of the United States Senate, Senator Thomas Dodd of Connecticut declared that he saw no need for the presence of a United Nations Representative in the Dominican Republic for it implied that the United Nations was attempting to compete with the OAS, and that this violated both rules of common sense and diplomacy. ${ }^{64}$ The Director of the Department of Legal Affairs of the Pan American Union emphasized that although the jurisdiction of the UN and the OAS in the Dominican case was concurrent, the sending of the UN Representative after the OAS had already taken charge and was obtaining results was an "abuse of power.,"es The Special Committee of the Tenth Meeting of Consultation, which had been entrusted with the duty of arranging a cease-fire and which had been given other responsibilities in the Dominican Republic, was also critical of the appearance on the scene of the UN Representative, pointing out that his intervention had a political effect which obstructed the progress of the Special Committee's negotiations with both factions. ${ }^{\circ}$

Nevertheless, as far as the relationship in Santo Domingo between the Representative of the Secretary General of the United Nations and the Inter-American Commission on Human Rights was concerned, the question of jurisdiction was functionally resolved. The Representative of the Secretary General and the Chairman of the Inter-American Commission held a series of meetings to exchange impressions. ${ }^{67}$ It was agreed that the Inter-American Commission would have charge of matters relating to the violation of human

\footnotetext{
${ }^{63}$ SCOR, S/PV. 1208, 14 May 1965, p. 6.

${ }^{84}$ As quoted by the Latin American Times, 2 July 1965, p. 2.

${ }^{\text {As }}$ Garcia Amador, supra note 60, at 3.

${ }^{6}$ Report of the Security Council, U.N. Security Council Off. Rec., op. cit. supra note 59 , at 105 .

${ }^{97}$ U.N. Security CounciL, Provisional Verbatim Record, op. cit. supra note 57, p. 6.
} 
rights in the Dominican Republic, and that in accordance with article 54 of the United Nations Charter, which declares that the Security Council should at all times be kept fully informed of the activities undertaken by regional agencies for the maintenance of international peace and security, the OAS would continue to inform the Secretary General of the United Nations. ${ }^{68}$

Actually it is very difficult to understand exactly what the UN Commission on Human Rights could have accomplished in the Dominican Republic. The competence of this Commission authorizes it to carry on the following activities:

1. Formulate an international bill of rights;

2. Formulate the recommendations for an international declaration or convention on such matters as civil liberties, the status of women, and freedom of information;

3. Seek the protection of minorities;

4. Prevent discrimination on the grounds of race, sex, language or religion, and

5. Consider any matters within the field of human rights likely to impair the general welfare or friendly relations among nations. ${ }^{69}$

In its first report to the UN, the UN Commission suggested that it be entrusted with the task of pointing out cases where a violation of human rights committed in one country could by its gravity, frequency or systematic nature constitute a threat to the peace. This implied that the Commission would review petitions of individuals whose human rights had been violated. ${ }^{70}$ This report aroused such opposition in certain quarters of the UN on the ground that such action would constitute intervention in the domestic affairs of a state, ${ }^{71}$ that in the following year the Commission laid down a general rule that it had no power to hear individual complaints concerning violation of human rights. ${ }^{72}$

This has been the accepted policy of the UN Commission on $\mathrm{Hu}$ man Rights since 1947. It would have constituted a complete break with the long established interpretation of its competence if the UN Commission had sought to undertake any of the tasks which the OAS Commission carried on in the Dominican Republic. ${ }^{73}$

${ }^{68}$ U.N. SEcurity CounciL, Letter From the Assistant Secretary General of the Organization of American States to the Secretary General of the United Nations, 29 June 1965, (transmitting preliminary report on human rights situation in the Dominican Republic submitted by Dr. Manuel Bianchi, Chairman of the Inter-American Commission on Human Rights, to the members of the Commission) (S/6495, 2 July 1965).

${ }_{69}$ U.N. Economic and Social Council Resolution of 16 February 1946 (Doc. No. E/20) set forth in Lauterpacht, International Law and Human Rights 224 (1950).

70 Journal of Economic and Social Council, First Year, No. 29, p. 522 (13 July 1946).

${ }^{71}$ These arguments are condensed in LAUTERPACHT op. cit. supra note 69, at 239.

72 U.N. Economic and Social Council Doc. No. $4 / 259$.

${ }^{73}$ LAUTERPACHT, op. cit. supra note 69, at 234. 
According to Dr. Dunshee de Abranches, one of the members of the Inter-American Commission on Human Rights, that Commission accomplished the following work:

a) Received and examined, up to August 30,1965,1105 denunciations, complaints and communications regarding violations;

b) Requested the competent authorities of the two governments to take pertinent measures to put an end to or prevent violations;

c) On various occasions visited all the prisons of the capital and the majority of those in the interior of the country, as well as military and naval establishments, for the purpose of informing itself of the conditions under which the political prisoners were kept;

d) Managed to achieve, in some cases that the conditions be improved, that the sick be attended, that the holdings of some persons incommunicado be ended, and that the prisoners who were held on mere suspicion be freed;

e) Requested installation of Boards of Investigation and Review, and the speeding up of their works, because of the precarious functioning of the organs of justice;

f) Addressed to the competent authorities, reports relating to executions and inhuman treatment of prisoners;

g) Attended to a large variety of special cases that were presented to it, as is shown in the partial reports prepared by the representatives of the Commission. ${ }^{74}$

Although certain members of the Security Council continued to press the UN Secretary General to instruct his representative in the Dominican Republic to investigate alleged violations of human rights, the Secretary General pointed out that under the mandate given by the Security Council, to his representative, he had only the duty of observation and reporting, and this did not cover the actual investigation of complaints and charges about specific incidents of violations of human rights. ${ }^{75}$ If the Security Council desired this, it would have to clarify the representative's powers by adopting a new resolution. But even without this resolution, one specific accusation was investigated by the UN Representative.

Having received information from various sources concerning alleged mass executions said to have been carried out by military and police elements of the "Government of National Reconstruction," at an estate known as "El Haras," the UN Representative visited the estate and found the remains of human bones and certain newly-dug graves. He passed this information on to the Chairman of the Inter-

\footnotetext{
${ }^{74}$ Dunshee de Abranches, A Special Protection of Human Rights in the Dominican Republic, at 3 (Washington World Conference on World Peace Through Law, T 7/6, Sept. 15, 1965).

${ }_{75}$ U.N. SECURITY CouncIL, Provisional Verbatim Record of the Twelve Hundred and Twenty-Tbird Meeting, p. 6 (Provisional, S/PV. 1223, 11 June 1965).
} 
American Commission on Human Rights, and also to the UN Secretary General. ${ }^{76}$ The Chairman of the Inter-American Commission on Human Rights immediately visited the scene, made arrangements for the Inter-American Peace Force to guard the area, and informed the Secretary General of the OAS. ${ }^{77}$ The Secretary General of the OAS, following the exchange of views with the Ad Hoc Committee, requested that a technical assistance mission, composed of criminologists and organized by the General Secretariat of the OAS, investigate and submit a detailed report. ${ }^{78}$ Upon its arrival in Santo Domingo on June 18, 1965, this three-man committee immediately contacted the UN Representative and the Inter-American Commission on Human Rights and obtained information and staff to aid in its work. Although the police and military offices of the "Government of National Reconstruction" offered its aid to the Special Committee of Criminologists, none was forthcoming. Furthermore, the criminologists stated:

reticence and fear ... seals the lips of the civilian population, generally modest and humble, which prefers to remain silent so as not to be exposed to risks or reprisals that they think would overcome them if they said what they knew. A system of acts of violence followed with impunity, instituted during the Trujillo era, seems not to have ceased to torment the population even today, several years after the elimination of the cruel tyrant. The mouths of the people continue to be closed. Ir would be said that their prudence assures their lives at least and they prefer to remain alive.

Such is the atmosphere of fear that we encountered, increased by the tragic findings of cadavers, which certainly have not diminished it. $^{79}$

The Inter-American Commission on Human Rights and the Special Committee of Criminologists finally established that probably forty-two persons had been executed. In the light of its investigation the criminologists concluded that members of the police or members of the army proceeded to apprehend civilians and accuse them of various offenses. They were then taken without higher control to a place under police and military command, and from there were systematically removed in night-time transfers to various spots and shot to death. The cadavers were often left unburied as a warning to others, although the people in the neighborhood generally buried

\footnotetext{
${ }^{78}$ U.N. Security Council, Report by the Secretary General (S/6432, 11 June $1965)$.

${ }^{77}$ PAU, Inter-American Commission on Human Rights, Human Rights Situation in The Dominican Republic 11 (OEA/Ser.L/V.II.12, Doc. No. 2, rev. 1965).

${ }^{78}$ U.N. Security Council, Cable From the Assistant Secretary General of the Organization of American States to the Secretary General of the United Nations, 16 June 1965 (S/6448, 16 June 1965).

${ }^{79} \mathrm{PAU}$, Tenth Meeting of Consultation of Ministers of Foreign Affairs, Doc. No. 231, p. S (OEA/Ser.F.11.10, 11 July 1965).
} 
them later. ${ }^{80}$ The criminologists placed the blame directly on the "Government of National Reconstruction" and stated that in view of the evidence, the authorities of this group were aware of the executions:

The circumstances that essentially similar acts took place in sites quite a distance from each other and on different dates leads to the thought not only of their military origin, but also of orders revealing a policy seeking to eliminate adversaries, executing them without trial, hurriedly leaving cadavers abandoned so that the fate of the victims would serve as a lesson and exemplary warning to the people. ${ }^{81}$

In view of the atrocities of the Nazi government during World War II the United States, the United Kingdom, France, and the Soviet Union, signed an agreement in 1945, establishing an International Military Tribunal at Nuremberg, Germany, with jurisdiction to try individuals for "crimes against humanity" which included murder and extermination as well as other inhumane acts committed against any civilian population before or during the war. ${ }^{82} \mathrm{Al}-$ though the Nuremberg Charter indicated that the responsibility involved was that of the authority of the state, nevertheless, the Tribunal declared that international law imposed duties and liabilities upon individuals as well as upon states, and concluded that crimes against international law are committed by men, not by abstract entities, and only by punishing individuals who commit such crimes can the provisions of international law be enforced. ${ }^{83}$ The Nuremberg judgment is a precedent for imputing criminal liability to individuals for crimes against humanity such as were committed in the Dominican Republic.

It has been argued that the Nuremberg Charter was merely an ephemeral measure enacted by the victor against the vanquished. On the other hand, by a resolution in December, 1946, the General Assembly of the UN unanimously affirmed the principles of international law recognized by the Charter and Judgment of the Nuremberg Tribunal. ${ }^{84}$ According to Dr. Schwarzenberger: "The minimum of legal significance that can be attributed to this Resolution is that, in the future, any member of the United Nations will be estopped

\footnotetext{
${ }^{80}$ Id. at 13 .

${ }^{81}$ Id. at 18 .

82 See 1 Trial of the Major War Criminais Before the International Military TribunaL X, XI (1946-47).

${ }^{83} 22$ Id. at $465-66$ (1948).

${ }^{84}$ U.N. Resolutions Adopted by the General Assembly During the Second Session Resolution 95(1), Affirmation of the Principles of International Law Recognized by the Charter of the Nuremberg Tribunal, taken at the ssth Meeting 11 Dec. 1946 (1947).
} 
from contesting the validity of these principles as rules of international law." ${ }^{35}$

The Draft Code of Offenses Against the Peace and Security of Mankind, adopted by the International Law Commission of the United Nations in 1951, also imputes criminal responsibility to individuals for acts which previously only engaged the responsibility of the state. It declares: "Offenses against the peace and security of mankind ... are crimes under international law, for which the responsible individuals shall be punished."s6 The Draft Code envisages two kinds of individual responsibility; one involves the responsibility of the authorities of the state, that is of the individuals who act as agents for the state; while the other engages the responsibility of private individuals participating in the unlawful acts.

The OAS criminologists pointed out that the authorities of the "Government of National Reconstruction" undoubtedly were aware of what was taking place. Furthermore, through their investigations the criminologists were "in possession of the names of police and military persons accused of participating in the acts, ${ }^{, 87}$ although they were not released in the report because it was felt that they should be "reserved for the cognizance of the judicial authorities charged with applying punishment to those found guilty in the corresponding trial." 88

The report of the criminologists definitely accused both policymaking officials in the "Government of National Reconstruction" and military and police personnel of that government of crimes against humanity. When the report was released, various Latin American diplomats felt that there should be some way to bring to justice those charged with these crimes, and there was again voiced the opinion that the OAS should create an Inter-American Court for the Protection of Human Rights. Furthermore, certain Latin American diplomats wanted to strengthen the Inter-American Human Rights Commission's mandate from that of "promoting" human rights to that of "protecting" human rights.

The problem of punishment internally within the Dominican Republic became moot on August 31, 1965, when both the "Government of National Reconstruction" and the "Constitutional Govern-

${ }^{85}$ Schwarzenberger, The Problems of an International Criminal Law, 3 Current Legax Prob. 263, at 291 (1950).

${ }^{86}$ For complete text see Internatronal Law Commission, Report Covering the Work of its Third Session, U.N. Gen. Ass. Off. Rec. 7th Sess., Supp. No. 9, at 10-14 (A/1858) (1951).

${ }^{87} \mathrm{PAU}$, op. cit. supra note 77 , at 18.

${ }^{88}$ Ibid.

${ }^{89}$ Latin American Times, 8 July 1965. 
ment" signed two documents: the Act of Dominican Reconciliation, which established a provisional government with the understanding that such government would proclaim a general amnesty, under which no officer or enlisted man of the armed forces could be submitted to court martial or subject to punishment of any kind for acts committed since April 23, 1965; and the Institutional Act, under which the general amnesty was extended to all persons who had committed acts under the cover of the prevailing political situation. ${ }^{90}$

The Special Delegation of Colombia to the Tenth Meeting of Consultation, in a note addressed to its President, pointed out that the approval given to the articles contained in the Act of Dominican Reconciliation and the Institutional Act by the members of the Ad Hoc Committee of the OAS in Santo Domingo could not in any manner bind the American States represented at the Tenth Meeting that had not voted on these issues. ${ }^{01}$ The Ad Hoc Committee agreed, stating that although it had assisted in the preparation of these documents, in its opinion, neither the Meeting of Consultation nor the Committee itself was a party thereto. In signing the documents the Ad Hoc Committee only certified that the parties agreed to comply with the terms. The documents were purely internal Dominican agreements and were not intended to state legal principles of the interAmerican juridical system. ${ }^{92}$ Consequently, it can be argued that if ever an appropriate forum could be found outside of the Dominican Republic, and if ever those guilty of crimes against humanity can be found outside the territory of the Dominican Republic, the internal general amnesty would not be binding.

The Institutional Act declared that the provisional government would hold elections within a period of no less than six and no more than nine months from the effective date of the act, and requested cooperation in holding these elections from the OAS including "the presence of the Inter-American Commission on Human Rights in the Dominican Republic, from the time of the entry into force of this institutional act until the elected government takes office." mission of the Commission, therefore, was not completed with the inauguration of the Provisional Government. As a matter of fact the Commission believed that its mandate was now somewhat extended. Where originally it had sought only to secure the funda-

\footnotetext{
${ }^{90}$ For texts of these acts see PAU, Tenth Meeting of Consultation of Ministers of Foreign Affairs, Doc. No. 363 (OEA/Ser.F/11.10, 7 Sept. 1965).

${ }^{91}$ PAU, Tenth Meeting of Consultation of Ministers of Foreign Affairs, Doc. No. 313, p. 6 (OEA/Ser.F/11.10, 20 Aug. 1965).

${ }^{02} \mathrm{PAU}$, Tenth Meeting of Consuliation of Ministers of Foreign Affairs, Doc. No. 320, p. 2 (OEA/Ser.F/11.10, 23 Aug. 1965).

${ }_{83}$ Article 51, Institutional Act, set forth in Doc. No. 363, p. 19, op. cit. supra note 90.
} 
mental rights of life, liberty, personal security and the physical integrity of individuals, now under the Institutional Act, since the Provisional Government would be responsible for supervising the civic process prior to the elections, it became the additional duty of the Commission to concern itself with rights essential for the effective exercise of the right to vote and the holding of free and democratic elections, such as those of suffrage, meeting, association and the like. ${ }^{94}$

At the Second Special Inter-American Conference, held in Rio, November 17-30,1965, it was noted that during the six year life of the Commission on Human Rights, it had been working constantly and devotedly to stimulate awareness of human rights and to have progressive measures taken to protect those rights, but because of its limited powers it was unable to do more than request information, prepare reports and studies, and formulate recommendations to the governments. A resolution was therefore adopted to expand the Commission's functions. In view of the refusal of the Council of the OAS to clarify and extend the competence of the Commission even in face of a recommendation to do so by the Eighth Meeting of Consultation of Ministers of Foreign Affairs, the Rio Conference took the bit in the teeth and requested the Commission to conduct a continuing survey of the observation of fundamental human rights in each of the member states of the organization, and authorized it to examine communications submitted to it and any other available information

so that it may address to the government of any American state a request for information deemed pertinent by the Commission, and so that it may make recommendations when it deems this appropriate, with the objective of bringing about more effective observance of fundamental human rights. ${ }^{95}$

It was ordered that the statute of the Inter-American Commission on Human Rights was to be amended in accordance with the provisions of this resolution. Thus the issue of whether or not the Commission could make recommendations to individual states was finally resolved.

In taking this action, the Conference was in effect giving binding force to the Commission's own interpretation of its competence as

\footnotetext{
${ }^{94}$ PAU, Inter-American Commission on Human Rights, Report on Work Accomplisbed During its Eleventh Session (Special), July 21-23, 1965, p. 11 (OEA/Ser.L/V.11.12, Doc. No. 10,1965$)$.

${ }^{95}$ PAU, Final Act, Second Special Inter-American Conference, Rio de Janeiro, Brazil, Nov. 17-30, 1965, Resolution XXII, Expanded Functions of the Inter-American Commission on Human Rights, at 32 (OEA/Ser.C/1.13, 1965).
} 
far as it related to hearing complaints from private individuals and making specific recommendations to individuals states. It is an established principle that any international body may give an interpretation of its competence. This autointerpretation, however, is not a "decision" in that it is neither final nor binding. The final and binding decision belongs solely to the body which has the power to modify or suppress the original autointerpretation. ${ }^{\circ}$ In the case of the OAS, this would be either the Inter-American Conference or the Meeting of Consultation of Ministers of Foreign Affairs. Some would argue that since the Commission from its inception heard complaints and made recommendations to individual states, it had established a customary law precedent which was merely reaffirmed by the resolution of the Second Special Conference. ${ }^{97}$ Nonetheless, this latter argument must be rejected because the Conference failed to approve another autointerpretation of its competence, namely the Commission's view of article 9-c of its statute which authorizes it: "To prepare such studies or reports as it considers advisable in the performance of its duties." In the Haitian Case and in the Cuban case, where the governments failed to permit the Commission to investigate civil rights within these nations, the Commission had published reports on the situations in these countries hoping thereby to bring the power of publicity to bear. The Conference refused to grant this attribute to the Commission; hence it in effect rejected the Commission's interpretation. In so doing, it left the Commission without any sanctioning authority whatsoever.

At best publication was a weak sanction, for dictatorial governments suppressed the reports within their own nations and paid little heed to the adverse comments on their laws or administrative procedures. Nevertheless, the members of the Commission are exceedingly astute; it may well be that they will find another route by which they can accomplish the same purpose. The Commission is now required to submit an annual report to the Inter-American Conference or Meeting of Consultation of Ministers of Foreign Affairs covering (1) the progress achieved in realization of the goals set forth in the American Declaration on the Rights and Duties of Man, (2) areas in which further steps are needed to give effect to human rights set forth in the Declaration, and (3) observations

\footnotetext{
${ }^{96}$ Gross, States as Organs of International Law and the Problem of Autointerpretation, Law and Politics in the World Community s9 (Lipsky ed., 1953).

97 "Unless we are prepared to abandon every principle of growth for International Law, we cannot deny that our own day has its right to institute customs ... that will themselves become sources of a newer strengthened International Law." Report to the President of the United States by Robert H. Jackson, Chief Counsel for the United States, the Nuremberg Case 14 (1947).
} 
on communications submitted to it. ${ }^{98}$ It is not stated that these reports must remain secret or unpublished. It would not seem improbable therefore that this broad mandate could, at least temporarily, be interpreted in such a manner as to include within this annual report sections censoring specific governments for violations of human rights.

\section{Comparison With European Commission}

The work and development of the Inter-American Commission on Human Rights contrasts with that of the only other extant regional commission, the European Commission of Human Rights. This latter body was established in order to ensure respect for the provisions of the European Convention for the Protection of Human Rights and Fundamental Freedoms which was signed in Rome in 1950 and entered into force in 1953 after it had been ratified by ten European nations. ${ }^{20}$ Subsequently, all of the other members of the Council of Europe, except France, ratified this treaty. Under its provisions, ratifying states guarantee to all persons within their jurisdiction a number of basic rights and freedoms most of which are similar to those set forth in the Universal Declaration of Human Rights adopted by the General Assembly of the United Nations. ${ }^{100}$ The European Commission of Human Rights permits one government to accuse another government before the Commission of violation of human rights, and also permits any person, non-governmental organization, or group of individuals claiming to be the victim of a violation by one of the signatories to appear before the Commission if the nation against which the complaint is made has declared that it recognizes the right of individual petition and if the individual complainant has previously exhausted all local remedies. ${ }^{101}$

Once it accepts a complaint the European Commission is "to secure a friendly settlement on the basis of respect for human rights." If settlement is reached, the Commission draws up a brief report stating the facts of the case and the solution thereof, and sends this report to the states concerned, to the Committee of Ministers and to the Secretary General of the Council of Europe for publication. If it fails to reach a settlement, the Commission draws up a report on the facts and states its opinion as to whether the facts found disclose a

\footnotetext{
${ }^{88}$ Meek, Toward New Dimensions for the OAS-The Second Special Inter-American Conference, 18 Americas 1, at 5 (1966).

${ }^{99}$ The text of the Convention establishing this Commission may be found in 1 EuropeAN YEARBOOK 317-41 (1951).

${ }^{100}$ For a discussion see Lauterpacht, The Universal Declaration of Human Rights, 25 British Yearbook of INT'L LaW 354 (1948).

${ }^{101}$ Articles $52-54$ of the Convention.
} 
breach by the state concerned of its treaty obligations. This report is then transmitted to the Committee of Ministers of the Council of Europe which is required to decide by a two-thirds majority whether or not there has been a violation of the Convention, and if so, what measures should be taken to remedy the situation. The signatories to the treaty have undertaken to regard as binding on them any such decision of the Committee of Ministers.

Since the Committee of Ministers is a political organ of the Council of Europe, it was recognized that any decision arrived at by this group would have political overtones. The question of whether a state has violated the provisions of a treaty is generally a legal rather than a political question; thus it was felt that the Commission of Human Rights should have an alternative judicial procedure open to it. Therefore, the Convention also provided for the establishment of the European Court of Human Rights. ${ }^{102}$ If the Commission desires a judicial rather than a political settlement, and if the state or states concerned have agreed to accept the jurisdiction of the Court either as compulsory or on an ad hoc basis for the particular complaint, the Court is seised of the case. The Court is not a court of first jurisdiction; that is, before it can hear a case there must first be a failure by the Commission to achieve a friendly settlement. As a result an individual complainant cannot go directly to the Court without first going to the Commission.

If a state is found to be guilty by either the Committee of Ministers or the Court, and if it fails to take steps to correct the situation, the Committee of Ministers may publish the report of the Commission of Human Rights if it has taken the case under consideration, or the Commission of Human Rights can suspend or eventually expel the member state from the Council of Europe if it fails to abide by the judgment of the Court. ${ }^{103}$

The right of individual petition is the major contribution of the European Commission on Human Rights toward developing international law, for the nations of Europe recognized that an individual whose rights were denied should be able to submit his complaint to an international organ directly without having to seek support of a government. If he had to seek support from a government which had denied him the human rights, he would not receive it; and if he had to seek support from another government, it would in effect transform the complaint of an individual into a dispute between states.

\footnotetext{
${ }^{102}$ See Robertson, European Court of Human Rights, 9 AM. J. Comp. LAw 3 (1960).
}

${ }^{103}$ Id. at 23 . 
In spite of the fact that the European Commission of Human Rights has a firm treaty basis and was established much earlier than its Western Hemisphere counterpart, it can be questioned whether in actuality it has done as much for human rights as has the InterAmerican Commission. As far as handling individual complaints, it nowhere approaches the Inter-American Commission. For example, between July 1955 and December 1962, the European Commission received over 1700 complaints, but the majority were rejected by the Commission on the grounds that the applicant had failed to exhaust his local remedies, or because the alleged violation took place before the entry into force of the treaty, or because the alleged violation was not covered by the convention or for similar reasons. By the end of 1962 only twenty-seven applications had sufficient appearance of admissibility that they had been referred to the respondent governments for comment and "only seven individual applications had actually been declared admissible." 104

The far less rigid procedural restrictions on the Inter-American Commission have given much more scope to that body to handle individual complaints, and consequently it has been seised of many more cases than the European Commission. Under its strict regulations, the European Commission would have been ineffective in a situation such as was faced by the Inter-American Commission in the Dominican Republic. Therefore, even though it lacks the sanctioning power given to the European Commission, it cannot be gainsaid that as far as the American Commission's work in the Dominican Republic was concerned, this constituted "the most advanced and complete form of international protection of human rights ever described in the history of the law of nations and international relations." 105

104 These figures are cited by Robertson, Human Rights in Europe 58 (1963).

${ }^{105}$ Dunshee de Abranches, op. cit. supra note 74 , at $S$. 